\title{
Antioxidant Activity of Oxalis tuberosa peel extracts
}

\author{
Actividad Antioxidante de extractos obtenidos de la cascara de Oxalis tuberosa
}

\author{
D.J. Dimas-López ${ }^{a}$, N. Güemes-Vera ${ }^{a *}$, J. Piloni-Martini ${ }^{a}$, A. Bernardino-Nicanor ${ }^{b}$, L. \\ González-Cruz ${ }^{b}$, S. Soto-Simental ${ }^{a}$, A. Quintero-Lira ${ }^{a}$
}

\begin{abstract}
:
Oxalis tuberosa it's an Andean crop that was introduced to Mexico by an intercultural exchange, it's a tuber rich in carbohydrates, calcium and iron, but also has antioxidants in the peel and pulp, making it ideal to reduce oxidative stress and apply it as an additive or preservative in food, however to increase the effectiveness it is necessary apply an extraction method of the bioactive compounds, this is why an extract based on Oxalis tuberosa peel flour and solvents was elaborated using: hexane (EH), acetone(EA), and ethanol(Ee) to evaluate the antioxidant capacity of this extracts. The principal methodology was the quantification of total phenolic compounds (TPC), DPPH scavenging assay, determination of the EC50 in DPPH and ABTS assay. In all the methods Ee showed significant differences $(\mathrm{p}<0.05)$ with $9.23 \mathrm{mEAG} / \mathrm{g}$ in TPC, a maximum inhibition percentage of $76.74 \%$ of DPPH radical and 789.6 mgEq. of Trolox at ABTS assay. Based on the results the use of ethanol is the most effective for extracting bioactive compounds as antioxidants, it will be possible to apply this compounds as additives to formulate functional foods or as preservatives to increase shelf life.
\end{abstract}

Keywords:

Oxalis tuberosa, extracts, antioxidant activity

\section{Resumen:}

La Oxalis tuberosa es un cultivo andino que fue introducido en México por un intercambio intercultural, es un tubérculo rico en carbohidratos, calcio y hierro, también posee antioxidantes en la cáscara y la pulpa, lo que lo hace ideal para reducir el estrés oxidativo y aplicarlo como aditivo o conservador en alimentos, para aumentar la efectividad es necesario aplicar un método de extracción de los compuestos bioactivos, es por eso que se elaboró un extracto a base de harina de cáscara de Oxalis tuberosa y solventes como: hexano (EH), acetona ( EA) y etanol (Ee) para evaluar la capacidad antioxidante de estos extractos. La metodología principal fue la cuantificación de compuestos fenólicos totales (TPC), el ensayo de inhibición de DPPH, la determinación de EC50 y ABTS. En todos los métodos Ee mostró diferencias significativas (p<0.05) con $9.23 \mathrm{mEAG} / \mathrm{g}$ en TPC, un porcentaje de inhibición máximo de $76.74 \%$ de radical DPPH y 789.6 mgEq. de Trolox en el ensayo ABTS. Con base a los resultados, el uso de etanol es el más eficaz para extraer compuestos bioactivos como antioxidantes, será posible aplicar estos compuestos como aditivos para formular alimentos funcionales o como conservantes para aumentar la vida útil.

\section{Palabras Clave:}

Lorem, ipsum, dolor, sit, amet

\section{Introduction}

a Autor de Correspondencia, Universidad Autónoma del Estado de Hidalgo, Instituto de Ciencias Agropecuarias, ORCID: 0000-0003-47544331, Email: norma_gueme@suaeh.edu.mx, dendimlop29@hotmail.com, chipiloni1@gmail.com, ssoto70@yahool.com, auroraq1@yahoo.com.mx.njgv2002@yahoo.com.mx

b Thechnological Institute of Celaya; Antonio García Cubas Pte 600 esq. Av. Tecnológico.Celaya, Gto. México. aureabernardino@yahoo.com, leopoldo.gonzalez@itcelaya.edu.mx

Red potato Oxalis tuberosa it's an andean, in Mexico the states that produce Oxalis tuberosa are Hidalgo, Puebla and Tlaxcala (Pérez, 2009). This variety it's source of 
carbohydrates, calcium and iron (Campos et al., 2006). Another apport of this tuber it's the antioxidant content (polyphenols, anthocyanins, and flavonoids) in the peel as it gives a reddish coloration and in a minor concentration in the pulp, among the polyphenols we find out benzoic, caffeic, vanillic and cinnamic acids, in the case of anthocyanins we find out malvidins and flavonoids as flavonoles and flavones (Chirinos, 2008).

Antioxidants are important due to the ability to inhibit or stabilize free radicals (ROS) which can induce oxidative stress, it has been found that antioxidants can act as antimicrobials by the inhibition of protein synthesis, rupture in the cell membrane causing damage to the cell metabolism (Lamb, 2011). Although the benefits of these bioactive compounds can be acquired directly from the product, it's recommendable to obtain them by any extraction method which allowed to concentrate them and increase their capacity as additives and preservative in the formulation of functional foods. That's why extracts were obtained from Oxalis tuberosa peel flour using ethanol, hexane and acetone as solvents evaluating the content of phenols and inhibit capacity of free radicals DPPH and ABTS.

\section{MATERIALS AND METHODS}

\section{PREPARATION OF FLOUR AND EXTRACT}

Red potato Oxalis tuberosa was peeled and dried at $55^{\circ} \mathrm{C}$, then grounded and sieved in mesh (Tyler No. 40-425). To make the extraction of the bio-compounds were used three solvents (ethanol. acetone and hexane 95\%) in a ratio $1: 1$, the solution was stocked for $48 \mathrm{~h}$ at $4^{\circ} \mathrm{C}$ after that it was filtered, the recuperated flour from the first extraction was macerated twice more, then the solvent of each extract was evaporated in rota-evaporator (Büchi. Modelo: R-215) and the extract was concentrated in heating grill at $35^{\circ} \mathrm{C}$ and stocked at $4^{\circ} \mathrm{C}$ until used.

\section{TOTAL PHENOLS}

The followed methodology from Singleton et al., (1999) making changes in the quantities used of the samples, the results were reported as Gallic acid equivalents. Different concentrations of the extracts were used $0.5 \mathrm{~g}$ of hexane extract $(E H), 0.007 \mathrm{~g}$ of acetone extract $(E A)$ and $0.004 \mathrm{~g}$ of ethanol extract $(\mathrm{Ee})$ they were dissolved in $5 \mathrm{~mL}$ of each solvent, $1.58 \mathrm{~mL}$ were taken from the solution and added $100 \mu \mathrm{L}$ of Folin Ciocalteu reactive, after 20 minutes at $50^{\circ} \mathrm{C}$ the absorbance was measured at $765 \mathrm{~nm}$ in a spectrophotometer SP-300 nano.

\section{DPPH, EC50}

A modification was made to the methodology proposed by Brand-Williams (1995) making an adaptation in plant materials, performing a general sweep of the samples to determine the concentrations in the kinetics of radical inhibition, $0.05 \mathrm{~mL}$ of the sample was taken then added $1.95 \mathrm{~mL}$ of the radical at $0.02 \mathrm{mMol}$, the absorbance was measured at $517 \mathrm{~nm}$ for $60 \mathrm{~min}$ in 10-minute intervals and the percentage of inhibition of the radical was determined.

\section{ABTS}

The ABTS reagent was mixed with potassium persulfate, the radical was standardized to absorption of $0.7 \pm 0.02 \mathrm{~nm}$ (Re et al., 2009). Were used $0.005 \mathrm{~g}$ of each concentrate $(E H, E A, E e)$ which were dissolved in $1.5 \mathrm{~mL}$ of the corresponding solvents, for the reaction were used 0.50 $\mathrm{mL}$ of the concentrate and $1.450 \mathrm{~mL}$ of the ABTS solution, the absorbance was measured at $732 \mathrm{~nm}$, the results are expressed in percentage of inhibition and TROLOX equivalents, so a standard curve was made.

\section{STATISTICAL ANALYSIS}

A completely randomized design was used, the extracts were evaluated by means of an analysis of variance (ANOVA) and the means were compared by the Tukey method using the IBM SPSS Statistics 20 software RESULTS

\section{FLOUR AND EXTRACT}

After the drying of the potato flakes, $3 \mathrm{~kg}$ of flour were obtained, which represents $3.5 \%$ of yield, while for the concentrates, $6.08 \mathrm{~g} \mathrm{Ee}, 0.96 \mathrm{~g} \mathrm{EA}$ and $0.98 \mathrm{~g}$ of EH were obtained, with a yield of $3.04 \%, 0.49 \%$ and $0.48 \%$ respectively. Ee presents a higher yield, this may be due to the bioactive compounds that are extracted by ethanol, since it is able to drag compounds such as flavonoids, anthocyanins, phenols and saponins, while hexane and acetone extract fats, hydrocarbons and carboxylic compounds by what its performance is significantly lower than Ee. The results obtained are similar to those of Yung et al. in 2013, whom made extracts with blueberry leaves in different stages of maturation using methanol, ethanol and acetone as solvents, having a better yield in the ethanol extract.

\section{TOTAL PHENOLS}

The concentrations used for each extract correspond to $158 \mathrm{~g} / \mathrm{L}$ for $\mathrm{EH}, 2.21 \mathrm{~g} / \mathrm{L}$ for EA and $1.26 \mathrm{~g} / \mathrm{L}$ for Ee, this due to the antioxidant capacity of each extract which corresponds to $0.0027 \mathrm{mgEAG} / \mathrm{mg}, 5.37 \mathrm{mgGAE} / \mathrm{mg}$ and $9.23 \mathrm{mgGAE} / \mathrm{mg}$ respectively, the concentrates show significant differences $(p<0.05)$, (Table $I)$ with Ee being the highest phenol content, which may be due to the type of solvent used. The results obtained are comparable with those of Rjeibi et al.2016 in terms of the extraction solvent since they used $\mathrm{MeOH}$ and $\mathrm{EtOH}$ in the extraction of biocompounds of Ficus microcarpa showing greater amount of polyphenols in $\mathrm{EtOH}$ with $217 \pm 9.03 \mathrm{mgGAE} / \mathrm{g}$ while that with $\mathrm{MeOH}$ they obtained $96 \pm 8.87 \mathrm{mgGAE} / \mathrm{g}$

1. DPPH, EC50

In the general scan of samples EA and Ee showed a 50\% inhibition of the DPPH radical, and proceeded to look for the minimum inhibitory concentration of the radical using concentrations of $0.012,0.016,0.20$ and $0.24 \mathrm{~g} / \mathrm{mL}$ for both extracts. However, EH did not show $50 \%$ inhibition, reaching only the inhibition of $33.85 \%$ at a concentration of $0.12 \mathrm{~g} / \mathrm{mL}$ (Table I). The minimum concentration for EA is $0.0227 \mathrm{~g} / \mathrm{mL}$ achieving $55 \%$ inhibition of the DPPH radical at $10 \mathrm{~min}$ of reaction and a maximum inhibition of $71.24 \%$ at $60 \mathrm{~min}$, on the other hand $\mathrm{Ee}$ has a concentration of $0.0129 \mathrm{~g} / \mathrm{mL}$ inhibiting $55.41 \%$ of the radical at minute 10 and finding a maximum of $76.74 \%$ inhibition at $60 \mathrm{~min}$ (Figure 1).

\section{ABTS}


All the concentrates showed significant differences $(p<0.05)$ (Table I) with Ee being the most effective in the inhibition of the ABTS radical, showing $62.48 \%$ inhibition and a concentration of $789.67 \mathrm{mgEq}$ of Trolox, followed by EA that had an inhibition of $55.52 \%$ and $692.3 \mathrm{mgEq}$ of Trolox while $\mathrm{EH}$ was the lowest inhibition percentage with $28.29 \%$ and $311 \mathrm{mgEq}$. of Trolox.

Regarding the DPPH and ABTS radicals, the percentage of EC50 inhibition is greater than that reported by Nono et al., in 2014, using root Dissotis thollonii, they found a maximum inhibition of the DPPH radical of $62.85 \%$ and of ABTS of $51.36 \%$ in the extract with ethanol, this may be due to the extraction conditions and to the raw material used
Lamb, A. J, Cushnie, T. P.,. (2011). Recent advances in understanding the antibacterial properties of flavonoids. International Journal of Antimicrobial Agents, 38, 99- 107.

Nono, R. N., Barboni, L., Teponno, R. B., Quassinti, L., Bramucci, M., Vitali, L. A., Tapondjou, A. L. (2014). Antimicrobial, antioxidant, antiinflammatory activities and phytoconstituents of extracts from the roots of Dissotis thollonii Cogn.(Melastomataceae). South African Journal of Botany, 93, 19-26.

Pérez, E. (2009):OXALIDACEAE Fascículo 64 Instituto de Ciencia y Tecnología A.C. 10-35.

Re, R., Pellegrini, N., Proteggente, A., Pannala, A., Yang, M., Rice Evans, C. (1999). Antioxidant activity applying an improved ABTS radical action decolonization assay. Free Radical Biology and Medicine. 26: $1231-1237$

Rjeibi, I., Ncib, S., Alimi, H., Ben Saad, A., Saïd, I., Souid, S. (2016). Comparison of phytochemicals, antimicrobial, and antioxidant capacities in different anatomical parts of Ficus microcarpa (Moraceae). Journal of Food Biochemistry.

\begin{tabular}{|c|c|c|c|}
\hline Extract & Total Phenols & DPPH, EC50 & 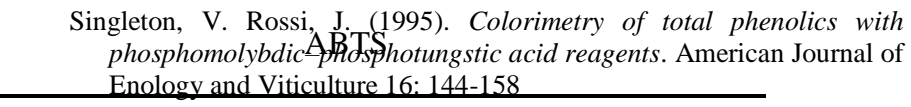 \\
\hline & mgGAE/mg & $\mathrm{CMI}(\mathrm{g} / \mathrm{mL})$ & $\begin{array}{l}\text { Eq. TROLOX Inhibition } \\
\text { Yung, D., Yang), G., Yue, J. (2013) Influences of ripening stages and }\end{array}$ \\
\hline $\mathrm{EH}$ & $0.0027^{\mathrm{a}}$ & $0.1200^{\mathrm{a}}$ & $\begin{array}{l}\text { extracting solvents on the polyphenolic compunds, antimicrobial and } \\
3 \text { duntidxidant activities of blueberry leaf8e2t9acts. Food Control, } 38,184-\end{array}$ \\
\hline EA & $5.37^{\mathrm{b}}$ & $0.0227^{b}$ & $55.52^{\mathrm{b}}$ \\
\hline $\mathrm{Ee}$ & $9.23^{c}$ & $0.0129^{c}$ & $62.48^{\mathrm{c}}$ \\
\hline
\end{tabular}

a,b,c, represent significative differences $\mathrm{p}<0.05$

\section{CONCLUSIONS}

The Ee concentrate shows significant differences in extraction performance and antioxidant activity compared to EA and EH, making it an excellent alternative for the addition of antioxidants in foods which can act in reducing the oxidation of the food itself or as a benefit to the consumer.

\section{REFERENCES}

Brand-Williams, W., Cuvelier, M. and Berset, C. (1995). Use of a free radical method to evaluate antioxidant activity. $L W T$. Food Science and Technology, 28(1), 25-30.

Campos, D., Noratto, G., Chirinos, R., Arbizu C., Roca, W. (2006): Antioxidant capacity and secondary metabolites in four species of Andean tuber crops: native potato (Solanum sp), mashua Tropaeolum tuberosum Ruiz \& Pavón), Oca (Oxalis tuberosa Molina) and ulluco (Ullucus tuberosus Caldas). Journal of the Science of Food and Agriculture, 86(10), 1481-1488.

Chirinos, R., Betalleluz-Pallardel, I., Huamán, A., Arbizu, C., Pedreschi, R. and Campos, D. (2009):HPLC-DAD characterisation of phenolic compounds from Andean oca (Oxalis tuberosa Mol.) tubers and their contribution to the antioxidant capacity. Food Chemistry, 113(4), 12431251 . 